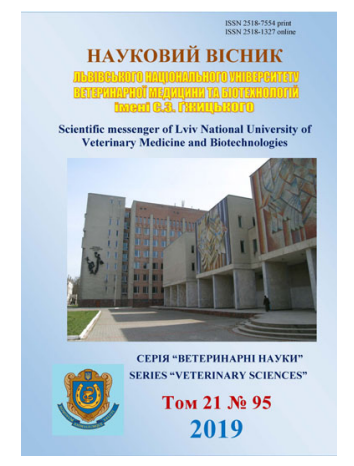

Науковий вісник Дьвівського національного університету ветеринарної медицини та біотехнологій імені С.3. Гжицького. Серія: Ветеринарні науки

Scientific Messenger of Lviv National University of Veterinary Medicine and Biotechnologies. Series: Veterinary sciences

UDC 594.3:616.99-098(477)

\title{
Parasitological studies of snails of different regions Ukraine
}

\author{
I.S. Danilova \\ National Scientific Center “Institute of Experimental and Clinical Veterinary Medicine”, Kharkov, Ukraine
}

Article info

Received 03.09.2019 Received in revised form 03.10 .2019

Accepted 04.10.2019

National Scientific Center "Institute of Experimental and Clinical Veterinary Medicine", Pushkinskaya street, 83, Kharkov, 61023, Ukraine Tel.: +38-067-305-93-51 E-mail: irrulik@meta.ua

\begin{abstract}
Danilova, I.S. (2019). Parasitological studies of snails of different regions Ukraine. Scientific Messenger of Lviv National University of Veterinary Medicine and Biotechnologies. Series: Veterinary sciences, 21(95), 32-35. doi: 10.32718/nvlvet9506

Dandelion (Gastropoda) is a numerical class of molluscs (about 130 thousand species), which representatives live in seas, salted and freshwater basins, and in wetlands on land. Clams in natural conditions are often infected with larvae of trematodes and some species of nematodes. Locus of localization of larvae is mostly hepatopancreas. Snails are no exception, they can also get sick, as a result, they become sluggish, refuse to eat, begin to allocate too thick mucus and so on. They can be infected: mites, parasites, nematodes, trematodes, bacteria, fungi. Parasites in snails may appear in several ways, namely: transferring from the soil or through entering new pupils who have not undergone quarantine. The consequences may be the most dangerous: contamination of the whole soil, mollusc diseases, human infection. Signs of infection are: lethargy, lack of appetite, slow growth, visual detection. The purpose of this work was to conduct a life-long and post-mortem diagnosis of helminthiasis of snails from different regions of Ukraine. The research was carried out on the snails of the species Helix pomatia from different regions of Ukraine, as well as on the Helix aspersa maxima and Helix aspersa muller artificial populations. From laboratory methods of diagnosis used coproscopic studies (research of faecal samples) of snails. For this purpose, a track of fecal snails was used, which was investigated by 3 methods - deposition method, expulsion method and compressor method. It was found that in samples 1 and 2, eggs and larvae were not detected, and in samples 3, 4 and 5, that is, in the snails of the natural population, nematodose was observed, as well as fungi were detected. This indicates that the external environment plays an important role in the cycle of nematode development. And this is regulated by factors such as temperature and humidity. In the conditions of the farm, these factors, as well as the possibility of skipping eggs or larvae, can be regulated through preventive measures: regulating the density of snails, using special soil, pasture, feed, water, and limiting contact with other snails and animals altogether. These factors are not at all possible in the snails of the natural population, therefore, in our opinion, samples of snails 3, 4 and 5 were more susceptible to nematodosis and infection with mushrooms than snails in samples 1 and 2. The prospect of our further research will be the histological study of hepatopancreas for nematodoznoy invasion.
\end{abstract}

Key words: parasitological studies, snail, life-long diagnosis, post-mortem diagnostics.

\section{Паразитологічні дослідження равликів різних регіонів України}

\author{
І.С. Данілова
}

Національний науковий иентр “Інститут експериментальної і клінічної ветеринарної медицини”, м. Харків, Украӥна

\footnotetext{
Черевоногі молюски (Gastropoda) - численний клас молюсків (близько 130 тис. видів), представники якого живуть у морях, солонуватих та прісноводних басейнах, а також у зволожених місиевостях на суші. Молюски в природних умовах нерідко вражаються личинками трематод і деяких видів нематод. Місием локалізації личинок є здебільшого гепатопанкреас. Равлики не є винятком, вони також можуть хворіти, внаслідок чого, стають млявими, відмовляються від їжі, починають виділяти надто густий слиз і таке інше. Вони можуть піддатися ураженню: кліщами, паразитами, нематодами, трематодами, бактеріями, грибами. Паразити в равликах можуть з'явитися кількома шляхами, а саме: занесення їх з трунту або через особин, які шойно надійшли до
} 
основної популяції равликів не пройшовши карантин. Наслідки можуть бути дуже небезпечними: ураження всього трунту, хвороба молюсків, ураження людини. Ознаками ураження є: млявість, відсутність апетиту, повільний ріст. Метою даної роботи було провести зажиттєву та посмертну діагностику гельмінтозів равликів з різних регіонів України. Дослідження проводили на равликах виду Helix ротатіа з різних регіонів Украӥни, а також на равликах Helix aspersa maxima та Неlix аspersa тиller штучної популяції. Встановлено, щзо у пробах 1 та 2 яєць та личинок не було виявлено, а у пробах 3, 4 та 5, тобто у равликів природньої популяиії, спостерігався нематодоз, а також виявляли гриби. Це свідчить про те, щзо зовнішнє середовище відіграє важливу роль у циклі розвитку нематод. I ие регулюється такими факторами, як температура та вологість. В умовах ферми иі фактори, а також можливість заносу яєць або личинок, можна регулювати шляхом профілактичних заходів: регулювання щільності равликів, використання спеціального трунту, пасовища, корму, води, а також обмеження контакту з іншими равликами і взагалі тваринами.

Ключові слова: паразитологічні дослідження, равлик, прижиттєва діагностика, посмертна діагностика.

\section{Ветуп}

Відносини між живими організмами, особливо між тваринами, здавна були предметом детального аналізу, спонукали дослідників до їхньої систематизації. Водночас розвиток різних галузей науки дає змогу щоразу глибше проникати в суть цих зв'язків, їхнє фізіологічне, метаболічне і генетичне підгрунтя. Проте ця проблема донині остаточно так і не вирішена (Nevyadomskaya et al., 2006; Sri-Aroon et al., 2010).

Відомо, що тварини, як і всі живі організми, перебувають між собою у певних зв'язках. Це може стосуватися особин, які належать до одного чи до різних видів. У вигляді, наприклад, вільних зв'язків або спеціалізованих угрупувань. Набагато складніший характер зв'язків у системах, що складаються з різних видів (Nevyadomskaya et al., 2006; Khvoroby vynohradnykh ravlykiv).

Черевоногі молюски (Gastropoda) - численний клас молюсків (близько 130 тис. видів), представники якого живуть у морях, солонуватих та прісноводних басейнах, а також у зволожених місцевостях на суші. Вони мають асиметричне тіло з головою та ніжкою, яке міститься переважно у конічно-спіральній мушлі кальцієвого складу.

Збудниками більшості хвороб є біогельмінти, тому дослідження проміжних, додаткових, резервуарних хазяїв паразитичних червів дають змогу з'ясувати гельмінтологічну ситуацію, прогнозувати появу паразитозів на конкрентних фермах, населених пунктах, районах, областях.

Проміжними хазяїнами біогельмінтів можуть бути сухопутні та прісноводні молюски, ракоподібні, комахи, кліщі, дощові черв'яки. Їх досліджують під малим збільшенням мікроскопу. Личинки гельмінтів локалізуються в різних органах і тканинах проміжних хазяїв (Sekretaryuk et al., 2005). Видовий склад молюсків - проміжних хазяїнів трематод і нематод - широкий. У них виявляють личинки дикроцеліуму, еуретреми, протостронгілід (Sekretaryuk et al., 2005).

Молюски в природних умовах нерідко вражаються личинками трематод і деяких видів нематод. Місцем локалізації личинок $є$ здебільшого гепатопанкреас. Він розміщений у верхівці мушлі. Їх досліджують компресорним методом під мікроскопом. За формою церкарії трематод нагадують пуголовків жаб (Sekretaryuk et al., 2005).

Кожна жива істота, що живе на планеті, піддається впливу зовнішніх факторів. Равлики не $\epsilon$ винятком, вони також можуть хворіти, внаслідок чого стають млявими, відмовляються від їжі, починають виділяти надто густий слиз і таке інше (Khvoroby vynohradnykh ravlykiv). Вони можуть вражатися кліщами, паразитами, нематодами, трематодами, бактеріями, грибами.

Також існує цілий спектр поверхових руйнувань, які залежать від навколишнього середовища і безпосередньо від догляду: травмування, отруєння, переохолодження, тепловий удар, пошкодження раковини, пухлини, відшарування мушлі від тіла.

Самі собою молюски є переносниками різноманітних паразитуючих організмів. При неправильних умовах утримання, розведення можна втратити всю популяцію.

Паразити в равликах можуть з'явитися кількома способами, а саме: перенесення 3 грунту або шляхом занесення через нових особин, які не пройшли карантину. Наслідки можуть бути дуже небезпечними: ураження всього грунту, хвороба молюсків, зараження людини (Urkkhart et al., 2000; Harlynska, 2014).

Ознаками ураження є: млявість, відсутність апетиту, повільний ріст.

Ще одна проблема, що може зашкодити равликам, - це гриби.

Вони можуть потрапити в ареал проживання і всі ці занепокоєння можуть бути з різних причин:

- $\quad$ уражений грунт

- $\quad$ зіпсована їжа

- $\quad$ кислі фрукти

- $\quad$ уражена особина, що не пройшла карантину.

За участю молюсків розвиваються трематоди, деякі нематоди і цестоди. Найбільш інвазованими вони бувають у другу половину літа і восени, якщо мова йде про равликів, що $\epsilon$ природньою популяцією (Smith, 1984; Harlynska, 2014).

Оскільки молюски є проміжними хазяїнами багатьох паразитів різних систематичних груп і вони $\epsilon$ кінцевою ланкою в циклі розвитку багатьох гельмінтів, то питання щодо даних паразитологічних досліджень равликів на сьогодні є актуальним.

Мета роботи. Провести прижиттєву та посмертну діагностику гельмінтозів равликів 3 різних регіонів України.

\section{Матеріал і методи досліджень}

Молюсків виду Helix pomatia збирали ручним способом у сиру погоду, після дощу або вранці, Helix aspersa maxima (проба 1) та Helix aspersa muller (проба 2) були отримані $з$ фермерського господарства 
“РАВЛИК 2016” (Україна). Для досліджень використовували по 15 равликів кожної проби.

Дослідження проводили на равликах виду Helix pomatia, які були зібрані у с. Казацьке Бериславського району Херсонської області (проба 3), с. Березна Полонського району Хмельницької області (проба 4), с. Мала Данилівка Дергачівського району Харківської області (проба 5).

3 лабораторних методів діагностики застосовували копроскопічні дослідження (дослідження проб фекалій) равликів. Для цього використовували “доріжку" 3 фекалій равликів, яку досліджували 3 методами: осадження, спливання та компресорним методом.

Метод послідовного промивання (осадження). Невелику кількість фекалій (5-10 г) розмішували у склянці з 10-кратною кількістю води. Суміш фільтрували крізь металеве сито або марлю і давали їй відстоятися упродовж 5 хв. Після цього верхній шар рідини зливали, а до осаду знову додавали таку ж кількість води і відстоювали 5 хв. Після просвітлення верхнього шару рідини в склянці, його зливали, а осад наносили на предметне скло і досліджували під мікроскопом (збільшення $10 \times 12,5$ ).

Метод Фюллеборна (флотації або спливання). У склянку вносили приблизно 5,0 г фекалій i, помішую- чи скляною паличкою, додавали насичений розчин кухонної солі (на одну частину фекалій 15-20 частин розчину солі). Для його приготування у 1,0 л кропу розчиняли 400,0 г солі. Отриманий розчин фільтрували крізь марлю або вату і після охолодження використовували. Суспензію фекалій фільтрували крізь металеве сито в іншу склянку і відстоювали упродовж 4050 хв. Яйця гельмінтів спливали. За допомогою металевої петлі діаметром не більше ніж 1,0 см відбирали три краплі рідини і переносили з поверхневого шару на предметне скло, після чого досліджували під мікроскопом (збільшення 10×12,5).

Компресорний метод. Равлика звільняли 3 мушлі спеціальною металевою петлею. Поміщали у чашку Петрі, розділяли на окремі шматочки з різними органами і тканинами та досліджували за допомогою компресоріуму (рис. 3) під мікроскопом (збільшення $10 \times 12,5)$.

\section{Результати та їх обговорення}

Проведені нами паразитологічні дослідження равликів з різних регіонів України наведені в таблиці 1.

\section{Таблиця 1}

Паразитологічні дослідження равликів, $\mathrm{n}=75$

\begin{tabular}{ccc}
\hline Проби & \multicolumn{2}{c}{ Результати діагностики гельмінтозів: } \\
\cline { 2 - 3 } равликів & Прижиттєої & Посмертної \\
\hline 1 & - & - \\
2 & Початкова стадія нематодозу та одиночні гриби & Початкова стадія нематодозу та одиночні гриби \\
4 & Личинки нематоди та яйця нематод, в полі зору від & Яйця нематод, в полі зору від 2 до 8 грибів \\
5 & Початкова стадія нематодозу та одиночні гриби & Початкова стадія нематодозу та одиночні гриби \\
\hline Примітка: “-” нічого не виявлено
\end{tabular}

За результатами таблиці 1 встановлено, що згідно 3 нашими дослідженнями у пробах 1 та 2 яєць та личинок не було виявлено. У пробах 3,4 та 5, тобто у равликів природньої популяції, спостерігався нематодоз (рис. 1), а також виявляли гриби (рис. 2). Це свідчить про те, що зовнішнє середовище відіграє важливу роль у циклі розвитку нематод. I це регулюється такими факторами, як температура та вологість. В умовах ферми ці фактори, а також можливість заносу яєць або личинок, можна регулювати шляхом профілактичних заходів: регулювання щільності равликів, використання спеціального грунту, пасовища, корму, води, а також обмеження контакту з іншими равликами і взагалі тваринами. Ці фактори неможливі у равликів природньої популяції, тому, на нашу думку, проби равликів 3, 4 та 5 були більш схильні до нематодозу та ураження грибами, ніж равлики у пробах 1 та 2.

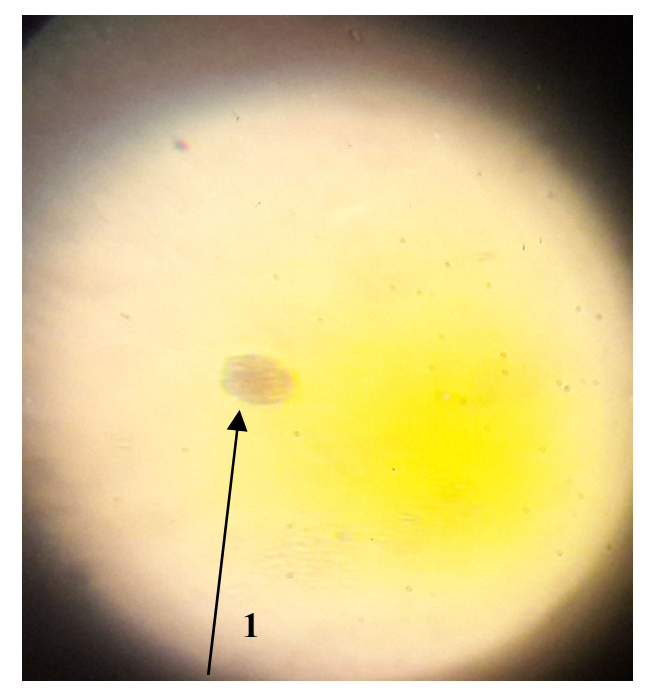

Рис. 1. Яйце нематоди (1) 


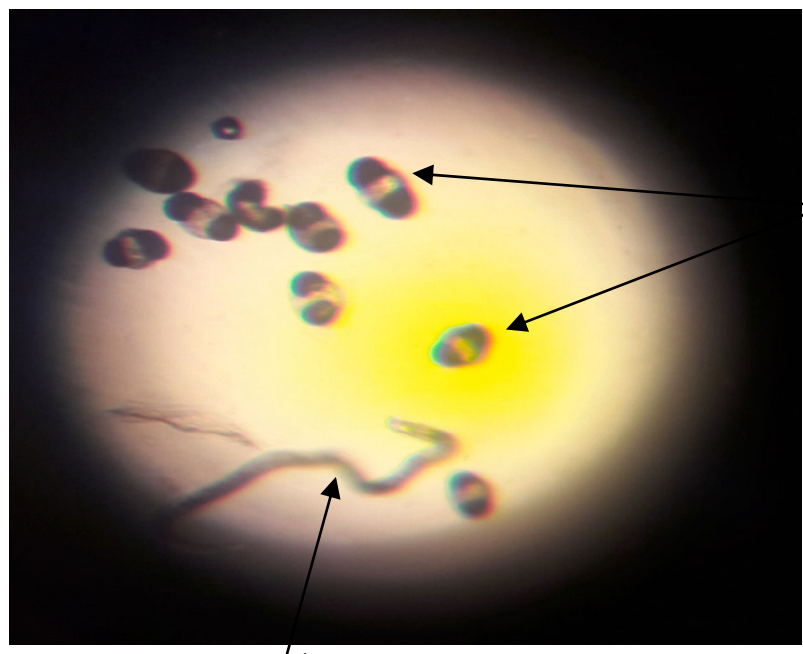

1

Рис. 2. Личинка нематоди (1) та гриби (2)

\section{Висновки}

1. Равлики можуть піддаватися ураженню грибами і нематодами, особливо це стосується молюсків природної популяції. Так, за результатами наших досліджень встановлено, що равлики природньої популяції, а саме, з Херсонської, Хмельницької та Харківської областей України, уражені в порівнянні 3 равликами фермерського господарства. Це можна пояснити тим, що в умовах господарства постійно контролюються усі умови щодо їх вирощування.

2. Обсіменіння яйцями і личинками нематод грунту, пасовищ, кормів, а також інвазовані безхребетні можуть бути факторами ураження інших тварин і людей. Тому обов'язковим правилом для фермерів 3 розведення равликів $є$ карантин для молюсків, які будуть надходити до ферми. Щоб не допустити ураження (вірусами, бактеріями, грибами) потрібно робити профілактичну дезінфекцію. Все, що контактує 3 особинами: грунт, їжа, приміщення має проходити очищення і оброблятися розчинами дезінфектантів згідно з інструкцією до застосування, але без присутності молюсків.

3. Перш ніж виготовляти будь-які страви з равликів, необхідно провести комплекс заходів, i обов'язковим елементом $\epsilon$ паразитологічні дослідження, особливо це стосується безхребетних природної популяції.

Перспективи подальших досліджень. Проведення гістологічних досліджень гепатопанкреаса за нематодозної інвазії.

\section{References}

Harlynska, A.M. (2014). Ekoloho-parazytolohichna kharakterystyka molyuskiv pidrodyny pukhyrchykovykh

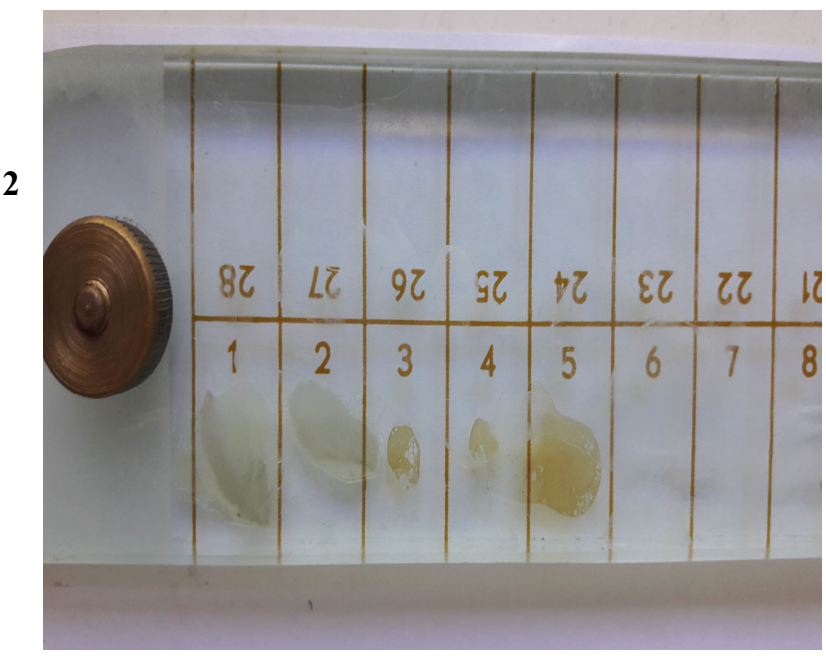

Рис. 3. Дослідження компресорним методом

(Gastropoda; Pulmonata; Physinae) Ukrayiny: monohrafiia [Ecological-parasitological characteristics of the subfamily mollusks (Gastropoda; Pulmonata; Physinae) of Ukraine: monograph]. Visnyk KHNU im. V.N. Karazina, 1126, 98-105 (in Ukrainian).

Khvoroby vynohradnykh ravlykiv [Diseases of grape snails]. Retrieved from: https://ukraine.snailshouse.com/illnesses-of-snail (in Ukrainian).

Nevyadomskaya, K., Poymanskaya, T., Magnitskaya, B., \& Chubay, A. (2006). Zahalna parazytolohiya : monohrafiia [General parasitology: monograph]. Kyyiv: Science (in Ukrainian).

Sekretaryuk, K.V., Svarchevskyy, O.A., \& Tafiychuk, R.I. (2005). Helmintolohichni doslidzhennya tvaryn i navkolyshnoho seredovyshcha u veterynarniy medytsyni: monohrafiia [Helminthological studies of animals and the environment in veterinary medicine: monograph]. Lviv: View of Spolom (in Ukrainian).

Smith, J.D. (1984). Development of Raphidascaris acus (Nematoda, Anisakidae ) in paratenic, intermediate, and definitive hosts. Can. J. Zool., 62(7), 1378-1386. doi: 10.1139/z84-198.

Sri-Aroon, P., Chusongsang, P., Chusongsang, Y., Pornpimol, S., Butraporn, P., \& Lohachit, C. (2010). Snails and Trematode infection after Indian Ocean tsunami in Phang-Nga Province, southern Thailand. Southeast Asian J Trop Med Public Health, 41, 48-60. https://www.ncbi.nlm.nih.gov/pubmed/ 20578482.

Urkkhart, G.M., Ermur, Dzh., Dunkan, Dzh., Dann, A.M., \& Dzhennings, F.V. (2000). Veterinarnaya parazitologiya : monohrafiia [Veterinary parasitology: monograph]. Moskva: Akvarium LTD (in Russian). 